\title{
STUDI PENDAHULUAN PEMBUATAN MINUMAN FERMENTASI-YOGHURT BERBAHAN DASAR BIJI DURIAN DAN ANALISIS KIMIANYA
}

Irma Ratna Kartika

Jurusan Kimia, Fakultas Matematika dan Ilmu Pengetahuan Alam, Universitas Negeri Jakarta, Rawamangun Jakarta 13220

*Corresponding author: irmaratna@unj.ac.id

\begin{abstract}
Abstrak
Penelitian ini bertujuan untuk mempelajari pembuatan minuman fermentasi berbahan dasar biji durian dan analisis kimianya. Minuman fermentasi ini dibuat dengan memvariasikan lamanya waktu fermentasi (20 jam, 30 jam, dan 40 jam) dan konsentrasi campuran serbuk biji durian dengan air (perbandingan biji durian:air adalah 1:16, 1:18 dan 1:20). Komposisi lengkap dari tiap-tiap yoghurt adalah sebagai berikut: Yoghurt $\mathrm{A}$ (5\% w/w susu skim, 5\% w/w gula pasir, 10\% starter bakteri asam laktat, dan $80 \%$ biji durian + air (perbandingan biji durian:air = 1:16)), Yoghurt B ( $5 \% \mathrm{w} / \mathrm{w}$ susu skim, $5 \% \mathrm{w} / \mathrm{w}$ gula pasir, $10 \%$ starter bakteri asam laktat, dan $80 \%$ biji durian + air (perbandingan biji durian:air = 1:18)), Yoghurt C $(5 \% \mathrm{w} / \mathrm{w}$ susu skim, 5\% w/w gula pasir, $10 \%$ starter bakteri asam laktat, dan $80 \%$ biji durian + air (perbandingan biji durian:air $=1: 20)$ ), dan Blangko (5\% w/w susu skim, 5\% w/w gula pasir, $10 \%$ starter bakteri asam laktat, dan $80 \%$ air). Tiap-tiap campuran tersebut dibagi tiga dan dimasukkan ke tiga botol steril yang diberi label 20 jam (Yoghurt A20, Yoghurt B20 dan Yoghurt C20), 30 jam (Yoghurt A30, Yoghurt B30 dan Yoghurt C30) dan 40 jam (Yoghurt A40, Yoghurt B40 dan Yoghurt $\mathrm{C} 40)$. Selanjutnya botol diinkubasi pada suhu ruang $\left(28-30^{\circ} \mathrm{C}\right)$ berdasarkan waktu yang tertera di masingmasing botol tersebut. Setelah selesai diinkubasi, tiap-tiap botol didinginkan didalam refrigerator sampai dilakukan analisis kimianya.

Hasil penelitian ini menunjukkan bahwa penampilan fisik dari minuman fermentasi biji durian adalah berupa larutan kental atau semipadat yang berwarna krem dan berbau tajam khas produk fermentasi bakteri asam laktat. Selain itu, waktu fermentasi berpengaruh terhadap kandungan kimia dari minuman fermentasi biji durian. Minuman fermentasi biji durian yang memiliki keasaman paling tinggi $(0,855$ setiap $100 \mathrm{mg}$ asam laktat/g sampel) dan kadar gula pereduksi yang paling tinggi $(2,641 \mathrm{mg} / \mathrm{mL})$ adalah minuman fermentasi dengan perbandingan biji durian:air = 1:16 pada waktu fermentasi 30 jam. Sementara itu, minuman fermentasi biji durian yang memiliki kandungan protein yang paling tinggi $(8,717 \mathrm{mg} / \mathrm{mL})$ adalah minuman fermentasi dengan perbandingan biji durian:air = 1:20 pada waktu fermentasi 30 jam. Kesimpulan penelitian ini adalah biji durian dapat digunakan sebagai media fermentasi bagi bakteri asam laktat. Penelitian selanjutnya adalah uji organoleptik (uji penerimaan konsumen), karakteristik kimiawi, fisika, dan biologis seperti kadar lemak, kadar abu, cemaran mikroba, dan jenis-jenis asam atau senyawa volatil yang terkandung dalam yoghurt biji durian agar dapat memenuhi standar yoghurt yang sesuai Standar Nasional Indonesia (SNI).
\end{abstract}

Kata Kunci: $\quad$ bakteri asam laktat, biji durian, minuman fermentasi, gula pereduksi, keasaman, Peptida

\begin{abstract}
This research is the preliminary study to test the avaibility of durian seed as fermented drink-yoghurt and its chemical analysis. The yoghurt was performed under a variety of fermentation time condition (20, 30 and 40 hr) and mixture concentration of durian seed powder and water (ratio of durian seed to water was 1:16, 1:18 and 1:20). The complete composition of yoghurts are Yoghurt $A$ (sugar 5\% w/w, skim milk 5\% w/w, 10\% w/w lactid acid bacteria starter and $80 \%$ of durian seed: water= 1:16), Yoghurt B (sugar $5 \% w / w$, skim milk $5 \% w / w$, $10 \% \mathrm{w} / \mathrm{w}$ lactid acid bacteria starter and $80 \%$ of durian seed:water $=1: 18$ ), Yoghurt C (sugar 5\% w/w, skim milk $5 \% \mathrm{w} / \mathrm{w}, 10 \% \mathrm{w} / \mathrm{w}$ lactid acid bacteria starter and $80 \%$ of durian seed:water $=1: 20$ ), and Blank (sugar 5\% w/ $w$, skim milk $5 \% \mathrm{w} / \mathrm{w}, 10 \% \mathrm{w} / \mathrm{w}$ lactid acid bacteria starter and $80 \%$ water). Every mixture was divided into three separated sterile bottles and bottles are labeled with 20hr (Yoghurt A20, Yoghurt B20 and Yoghurt C20), 30 hr (Yoghurt A30, Yoghurt B30 and Yoghurt C30) and and $40 \mathrm{~h}$ (Yoghurt A40, Yoghurt B40 and Yoghurt C40). Bottles were incubated at room temperature $\left(28-30^{\circ} \mathrm{C}\right)$ for 20,30 and $40 \mathrm{hr}$. After incubation, every bottle was cooled and ready to its chemical analysis.
\end{abstract}

The results indicated that performance of yoghurt was creamy, semisolid product and had strong acidic smell of the fermentation product. In addition, the fermentation time affected chemical composition of yoghurt. 
Yoghurt A30 (means: yoghurt A with incubation time of $30 \mathrm{hr}$ ) had highest total acid (0,855 every $100 \mathrm{mg}$ of lactic acid/g sample) and highest reducing sugar level $(2,641 \mathrm{mg} / \mathrm{mL})$. Meanwhile, the yoghurt C30 had only highest protein level $(8,717 \mathrm{mg} / \mathrm{mL})$. The conclusion of the study was durian seed is available for yoghurt preparation. Further, the research focuses on organoleptic study.

Key words: $\quad$ lactic acid bacteria, durian seed, reducing sugar, fermented drink, acidity, protein

\section{Pendahuluan}

Salah satu upaya yang bertujuan untuk memanfaatkan biji durian menjadi bahan pangan alternatif yang memiliki kandungan gizi yang tinggi sehingga bahan pangan tersebut bernilai ekonomis tinggi adalah dibuat minuman fermentasi berupa yoghurt berbahan dasar biji durian.

Penelitian mengenai pemanfaatan biji durian sebagai bahan dasar minuman fermentasi belum pernah dilakukan, padahal kandungan gizi dari biji durian tidak jauh berbeda dengan kacang kedelai dan ubi jalar oranye. Dalam 100 gram biji durian tanpa kulit luar diantaranya terkandung 2,6 g protein dan 43,6 g karbohidrat. Kandungan protein tersebut (2,6 g dalam $100 \mathrm{~g}$ biji durian) ternyata nilainya hampir mendekati kandungan protein susu sapi 3,2 g dalam 100 g susu sapi) (Brown, 1997). Oleh karena itu, penelitian pendahuluan tentang penggunaan biji durian sebagai bahan (dasar pembuatan minuman fermentasiyoghurt) sangat relevan untuk dilakukan. Dengan adanya penelitian ini, diharapkan limbah biji durian dimanfaatkan menjadi bahan pangan yang memiliki nilai gizi dan nilai ekonomis yang tinggi, serta memperkaya ragam pangan fungsional yang berasal dari limbah biji buah-buahan.

\section{Metodologi Penelitian}

\subsection{Pengolahan Sampel}

Durian yang digunakan adalah spesies Durio zibethinus yang berasal dari Palembang dan diperoleh dari penjual buah durian yang berdagang di Perumahan Villa Nusa Indah, Bekasi. Biji durian dicuci sampai bersih dan dikeringanginkan pada suhu ruang. Setelah agak kering, biji durian dipisahkan dari bagian kulitnya, dipotong-potong, lalu dimasukkan ke dalam oven pada suhu $\pm 100^{\circ} \mathrm{C}$ sampai kering (sekitar lima jam). Setelah kering, biji durian tersebut dihaluskan dengan blender selama \pm 2 menit sampai menjadi serbuk.

\subsection{Bahan Kimia}

Bahan-bahan yang digunakan antara lain biji durian, air mineral (Aqua, PT. Tirta Investama), starter campuran Lactobacillus delbrueckii subsp. bulgaricus, Streptococcus thermophilus dan Lactobacillus acidophilus telah siap dipakai (diperoleh dari Easiyo, Amway Pte Ltd), susu skim steril (Nesvita Prodigest, PT.Nestle), gula pasir (Gula 9, PT. Perkebunan Nusantara IX). Bahan-bahan dan reagen-reagen kimia adalah produksi E-Merck dengan tingkat spesifikasi Pro Analys (p.a.), antara lain indikator fenolftalein, $\mathrm{NaOH}$, $\mathrm{CuSO}_{4} .5 \mathrm{H}_{2} \mathrm{O}, \mathrm{KNaC}_{4} \mathrm{H}_{4} \mathrm{O}_{6}, \mathrm{Na}_{2} \mathrm{CO}_{3}, \mathrm{NaOH}$, Reagen Folin-Ciocalteu, buffer $\mathrm{pH} 4$, buffer $\mathrm{pH} 7, \mathrm{NaCO}_{3}$, $\mathrm{NaHCO}_{3}, \mathrm{Na}_{2} \mathrm{SO}_{4}, \mathrm{H}_{2} \mathrm{SO}_{4} 98 \%, \mathrm{Na}_{2} \mathrm{HAsO}_{7} .7 \mathrm{H}_{2} \mathrm{O}$, $\mathrm{ZnSO}_{4} .6 \mathrm{H}_{2} \mathrm{O}, \quad \mathrm{Ba}(\mathrm{OH})_{2}, \quad \mathrm{H}_{2} \mathrm{C}_{2} \mathrm{O}_{4}, \quad$ dan $\left(\mathrm{NH}_{4}\right)_{6} \mathrm{Mo}_{7} \mathrm{O}_{24}$.

\subsection{Alat-alat yang Digunakan}

Alat-alat yang digunakan antara lain blender, autoklaf, pisau, corong, botol gelas gelap ukuran $125 \mathrm{~mL}$, vakum evaporator, kertas Whatman no. 3, refrigerator, spektrofotometer UV-Vis Beam Labomed 2700, pH meter Hanna Instrument $\mathrm{HI}$ 8414, alat-alat gelas Pyrex, spatula kaca, spatula besi, dan mikro pipet Ependorf ukuran $1000 \mu \mathrm{L}$.

\subsection{Penetapan Perbandingan Biji Durian}

Penetapan perbandingan biji durian terhadap air berdasarkan pada penelitian yang telah dilakukan sebelumnya, yaitu penelitian Dwi (2005) untuk sari ubi jalar dengan 


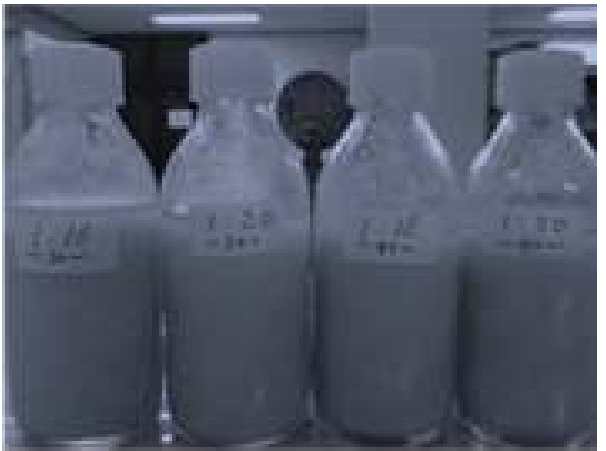

Gambar 1. Sampel Minuman Fermentasi Biji Durian (diameter botol adalah $15 \mathrm{~cm}$ )

konsentrasi ubi terhadap air yaitu 1:3, 1:5 dan 1:7. Berdasarkan penelitian diatas, maka dilakukan percobaan untuk menentukan konsentrasi biji durian yang akan digunakan. Setelah dilakukan tiga kali percobaan, disimpulkan bahwa jika menggunakan perbandingan biji durian : air =1:3, 1:5 dan 1:7 akan dihasilkan tekstur yang sangat padat dan lengket. Selain itu, perlu adanya zat aditif dalam yoghurt untuk memicu pertumbuhan populasi bakteri asam laktat. Berdasarkan hasil percobaan diatas pula, ditetapkan perbandingan biji durian:air yang digunakan yaitu sebesar 1:16, 1:18 dan 1:20.

Kadar penambahan gula pasir didasarkan pada penambahan gula dan susu skim yang lazim digunakan untuk pembuatan yoghurt yakni $5 \% \mathrm{w} / \mathrm{w}$, sedangkan penambahan starter bakteri asam laktat sebanyak $10 \% \mathrm{w} / \mathrm{w}\left(10^{8}\right.$ koloni/g), yaitu lebih besar $5 \% \mathrm{w} / \mathrm{w}$ dari jumlah starter yang umumnya digunakan pada pembuatan yoghurt.

Lamanya fermentasi yang lazim digunakan pada pembuatan yoghurt adalah overnight atau 24 jam pada suhu fermentasi $37^{\circ} \mathrm{C}$. Waktu fermentasi optimal dari pembuatan yoghurt biji durian kemungkinan besar berada diatas 24 jam karena suhu fermentasi yang digunakan pada penelitian ini lebih kecil dari $37^{\circ} \mathrm{C}$, yakni suhu ruang $28-30^{\circ} \mathrm{C}$. Oleh karena itu, waktu fermentasi dari minuman fermentasi biji durian dipilih 20 jam, 30 jam, dan 40 jam.

\subsection{Pembuatan Minuman Fermentasi}

Serbuk biji durian steril dicampur dengan air mineral steril dengan perbandingan massa biji durian dengan air adalah 1:16. Campuran dibuat sebanyak jumlah waktu fermentasi. Hal yang pertama dilakukan adalah menjalankan proses pasteurisasi yaitu dengan cara mencampurkan susu skim $5 \% \mathrm{w} / \mathrm{w}$, gula pasir $5 \% \mathrm{w} / \mathrm{w}$, air dan biji durian dengan perbandingan 1:16 kedalam panci dan dididihkan dengan pemanas pada suhu $\pm 80^{\circ} \mathrm{C}$ selama 15 menit. Setelah sekitar 15 menit, pemanas dimatikan, panci diangkat, lalu ditunggu hingga suhu menurun sekitar $40^{\circ} \mathrm{C}$ atau suam-suam kuku. Ketika suhunya sudah mencapai $\pm 40^{\circ} \mathrm{C}$, pada larutan campuran dilakukan proses inokulasi bakteri, yaitu pada panci ditambahkan starter bakteri asam laktat $10 \% \mathrm{w} / \mathrm{w}\left(10^{8}\right)$ dan diaduk hingga merata.

Setelah merata, larutan campuran dibagi dan dimasukkan kedalam tiga buah botol gelap dengan perbandingan massa yang kira-kira sama. Semua proses dilakukan secara hati-hati untuk menghindari terjadinya kontaminasi bakteri lain selain bakteri asam laktat. Setelah itu, pada ketiga tabung diberi label 20, 30, dan 40 jam yang menandakan waktu fermentasi dari masing-masing sampel yang ada pada botol tersebut. Campuran kemudian diinkubasi sesuai dengan lamanya waktu fermentasi.

Langkah-langkah di atas juga dilakukan terhadap sampel yang memiliki perbandingan air dengan biji durian 1:18 dan 1:20, serta blangko, yaitu larutan campuran yang terdiri 


\section{Laktosa $\longrightarrow$ Glukosa + Galaktosa}

Gambar 2. Reaksi Pemecahan Polisakarida (Laktosa) oleh Bakteri Asam Laktat (Sumber: Zourari et al., 1992)

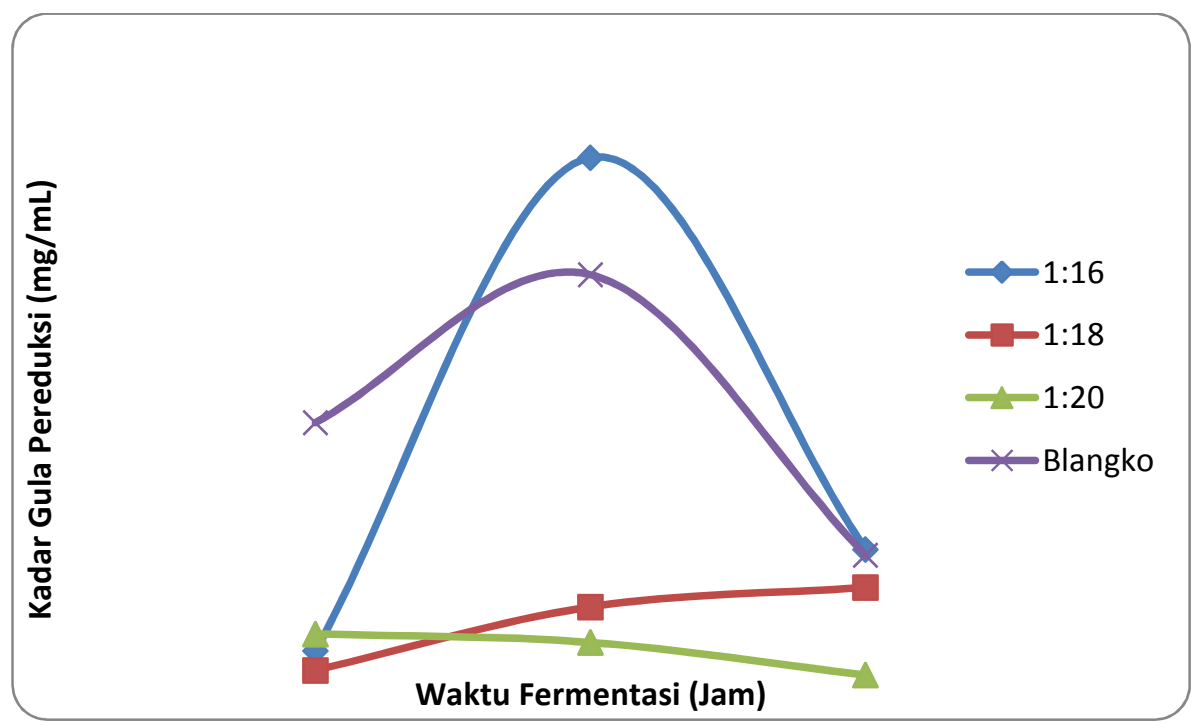

Gambar 3. Hubungan Antara Lamanya Fermentasi dengan Kadar Gula Pereduksi Minuman Fermentasi Biji Durian

atas susu skim $5 \% \mathrm{w} / \mathrm{w}$, gula pasir $5 \% \mathrm{w} / \mathrm{w}$, dan air $80 \% \mathrm{w} / \mathrm{w}$. Komposisi lengkap dari tiap-tiap yoghurt adalah sebagai berikut:

Yoghurt $\mathrm{A}=5 \% \mathrm{w} / \mathrm{w}$ susu skim, $5 \% \mathrm{w} / \mathrm{w}$ gula pasir, 10\% starter bakteri asam laktat, dan $80 \%$ biji durian + air (perbandingan biji durian:air $=1: 16)$.

Yoghurt $\mathrm{B}=5 \% \mathrm{w} / \mathrm{w}$ susu skim, $5 \% \mathrm{w} / \mathrm{w}$ gula pasir, 10\% starter bakteri asam laktat, dan $80 \%$ biji durian + air (perbandingan biji durian:air $=1: 18$ ).

Yoghurt $\mathrm{C}=5 \% \mathrm{w} / \mathrm{w}$ susu skim, $5 \% \mathrm{w} / \mathrm{w}$ gula pasir, $10 \%$ starter bakteri asam laktat, dan $80 \%$ biji durian + air (perbandingan biji durian:air $=1: 20$ ).

Blangko $=5 \% \mathrm{w} / \mathrm{w}$ susu skim, $5 \% \mathrm{w} / \mathrm{w}$ gula pasir, $10 \%$ starter bakteri asam laktat, dan $80 \%$ air.

Untuk menumbuhkan bakteri dan agar fermentasi terjadi, dilakukan inkubasi di laboratorium Penelitian Kimia dengan menggunakan suhu ruang $\left( \pm 28-32^{\circ} \mathrm{C}\right)$. Setelah itu, semua botol dimasukkan kedalam refrigerator untuk memperlambat proses fermentasi sampai dilakukan analisis kimia terhadap botol-botol tersebut.

\subsection{Analisis Kimia}

Analisis kimia terhadap yoghurt meliputi penentuan total asam, penentuan kadar protein, penentuan derajat keasaman dan penentuan kadar gula pereduksi. Penentuan total asam dilakukan dengan memasukkan filtrat minuman fermentasi sebanyak $5 \mathrm{~mL}$ ke dalam labu Erlenmeyer ukuran $100 \mathrm{~mL}$, ditambahkan indikator fenolftalein sebanyak 3 tetes, kemudian larutan tersebut dititrasi dengan larutan $\mathrm{NaOH} 0,1 \mathrm{~N}$ yang telah distandarkan. Titrasi dihentikan jika warna larutan telah menjadi merah muda. 


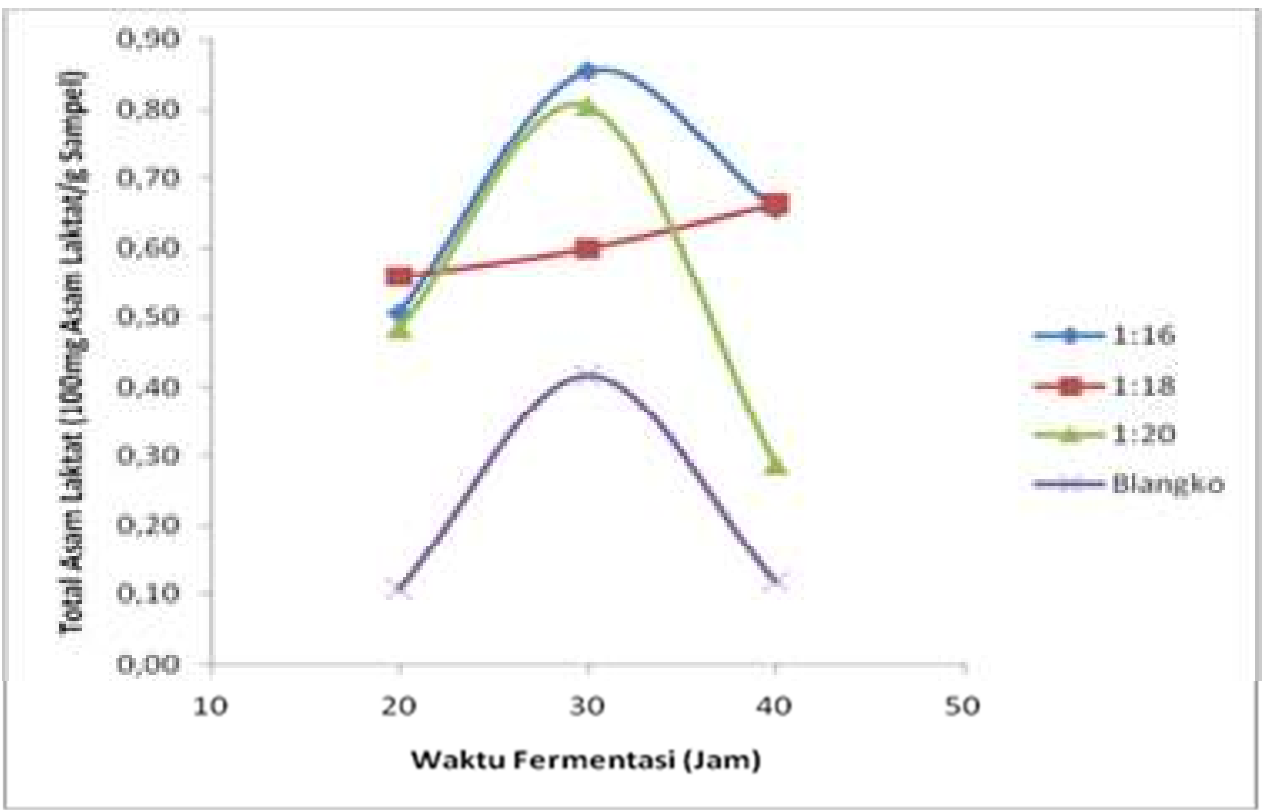

Gambar 4. Hubungan Antara Waktu Fermentasi dengan Total Asam Minuman Fermentasi Biji Durian

Penentuan kadar protein dilakukan dengan memipet sampel-sampel filtrat minuman fermentasi sebanyak $0,05 \mathrm{~mL}$, dimasukkan kedalam botol-botol kecil, ditambah akuades sebanyak 0,55 mL, diaduk hingga merata, lalu ditambah masing-masing sebanyak $3,0 \mathrm{~mL}$ Reagen Lowry, diaduk dengan cepat dan dibiarkan selama 10 menit. Setelah itu larutan campuran ditambah $0,15 \mathrm{~mL}$ reagen FolinCiocalteu, diaduk dengan cepat dan dibiarkan selama 30 menit. Kemudian larutan-larutan campuran tersebut diukur absorbansinya pada panjang gelombang maksimum.

Penentuan derajat keasaman dilakukan dengan alat $\mathrm{pH}$ meter. $\mathrm{pH}$ meter dinyalakan dan dikalibrasikan. Elektroda dicuci dengan akuades dan dikeringkan dengan tissu. Elektroda kemudian dicelupkan ke dalam sampel filtrat minuman fermentasi hingga diperoleh pembacaan konstan dari nilai $\mathrm{pH}$ filtrat tersebut.

Penentuan gula pereduksi dilakukan dengan memipet sampel-sampel filtrat minuman fermentasi sebanyak $0,1 \mathrm{~mL}$ lalu ditambah akuades 0,9 mL. Larutan dikocok, dipipet kembali sebanyak 0,1 $\mathrm{mL}$, dan dimasukkan kedalam botol kecil yang berisi 1,5 $\mathrm{mL}$ air, kemudian diaduk sampai homogen. Larutan kemudian ditambah $0,2 \mathrm{~mL} \mathrm{Ba}(\mathrm{OH})_{2}$ 0,3 $\mathrm{N}$, dikocok beberapa saat, lalu ditambah $0,2 \mathrm{~mL}$ $\mathrm{ZnSO}_{4} 5 \% \mathrm{w} / \mathrm{v}$, dikocok, kemudian dimasukkan kedalam tabung sentrifuge dan disentrifuge selama 5 menit. Setelah disentrifuge, $1 \mathrm{~mL}$ supernatan dipindahkan kedalam botol kecil dan ditambah $1 \mathrm{~mL}$ pereaksi Cu-alkalis (larutan campuran Nelson A : Nelson B $=4: 1$ ). Botol ditutup, kemudian dipanaskan didalam penangas air selama 10 menit. Setelah 10 menit, botol-botol diangkat dan didinginkan. Setelah dingin, ditambah $1 \mathrm{~mL}$ pereaksi Arsenomolibdat. Larutan dibiarkan beberapa saat sampai tidak timbul gelembung-gelembung udara. Setelah itu, larutan diencerkan hingga volume $10 \mathrm{~mL}$ dan didiamkan untuk pembentukan warna yang sempurna minimal selama 1 jam. Setelah itu, larutan-larutan campuran tersebut di ukur absorbansinya pada panjang gelombang maksimum. 


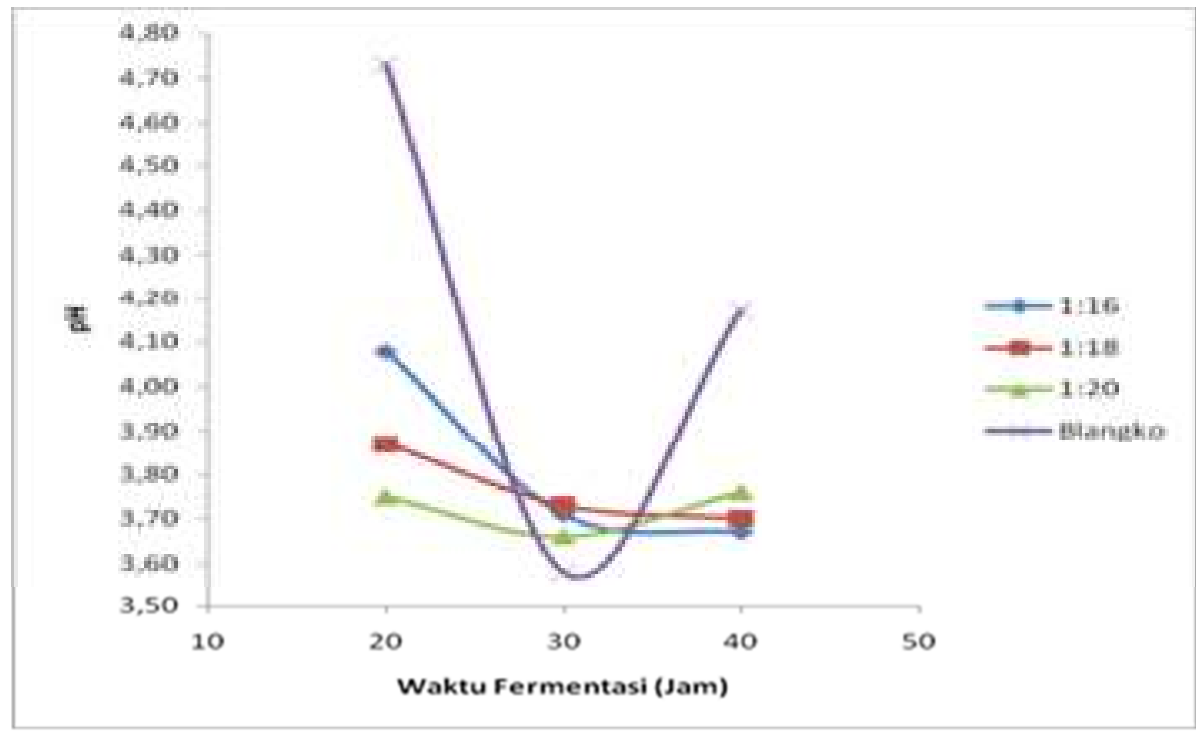

Gambar 5. Hubungan Antara Waktu Fermentasi dengan Nilai pH Minuman Fermentasi Biji Durian

\section{Hasil dan Pembahasan}

Bakteri asam laktat menggunakan glukosa sebagai sumber energi. Oleh karena itu, bakteri asam laktat perlu memecah polisakarida menjadi glukosa dan galaktosa, yang merupakan jenis gula pereduksi, untuk digunakan sebagai sumber energi bagi pertumbuhannya. Reaksi yang terjadi pada pembentukan gula pereduksi dalam susu fermentasi disajikan pada Gambar 2.

Hubungan antara lamanya fermentasi dengan kadar gula pereduksi dalam yoghurt biji durian ditunjukkan pada Gambar 3. Berdasarkan Gambar 3, pada blangko terlihat kadar gula pereduksi naik di waktu fermentasi jam ke-20 sampai jam ke-30. Hal ini menandakan bahwa telah terjadi peningkatan pemecahan polisakarida menjadi monosaridamonosakaridanya. Peningkatan ini disebabkan pada interval waktu tersebut diyakini bakteri berada pada fase eksponensial (fase log), dimana aktivitas pembelahan atau pelipatgandaan jumlah bakteri berada pada kondisi optimal. Hal ini menyebabkan kebutuhan akan glukosa (sebagai gula pereduksi) juga meningkat. Peningkatan pada kebutuhan gula pereduksi juga meningkatkan aktivitas pemecahan polisakarida yang menyebabkan kandungan gula pereduksi dalam blangko juga meningkat dan dalam jumlah yang berlebih terhadap populasi bakteri, sehingga dari kurva terlihat adanya peningkatan kadar gula pereduksi.

Pada waktu fermentasi antara jam ke-30 sampai jam ke-40, terlihat bentuk kurva yang menurun. Bentuk kurva yang menurun ini menandakan pada interval waktu fermentasi tersebut jumlah glukosa dalam blangko menurun. Penurunan jumlah glukosa disebabkan bakteri asam laktat telah memasuki fase stasioner atau mendekati fase kematian, dimana pertumbuhan bakteri terganggu karena akumulasi asam laktat yang tidak dapat ditolelir oleh bakteri. Pembelahan bakteri yang terganggu menyebabkan jumlah populasi bakteri tetap. Bakteri dengan populasi yang tetap ini juga memanfaatkan glokosa sebagai sumber energi sehingga aktivitas pemecahan polisakarida yang terganggu tidak sebanding dengan aktivitas penggunaan glukosa yang tersedia sebagai sumber energi bagi bakteri untuk bertahan hidup. 


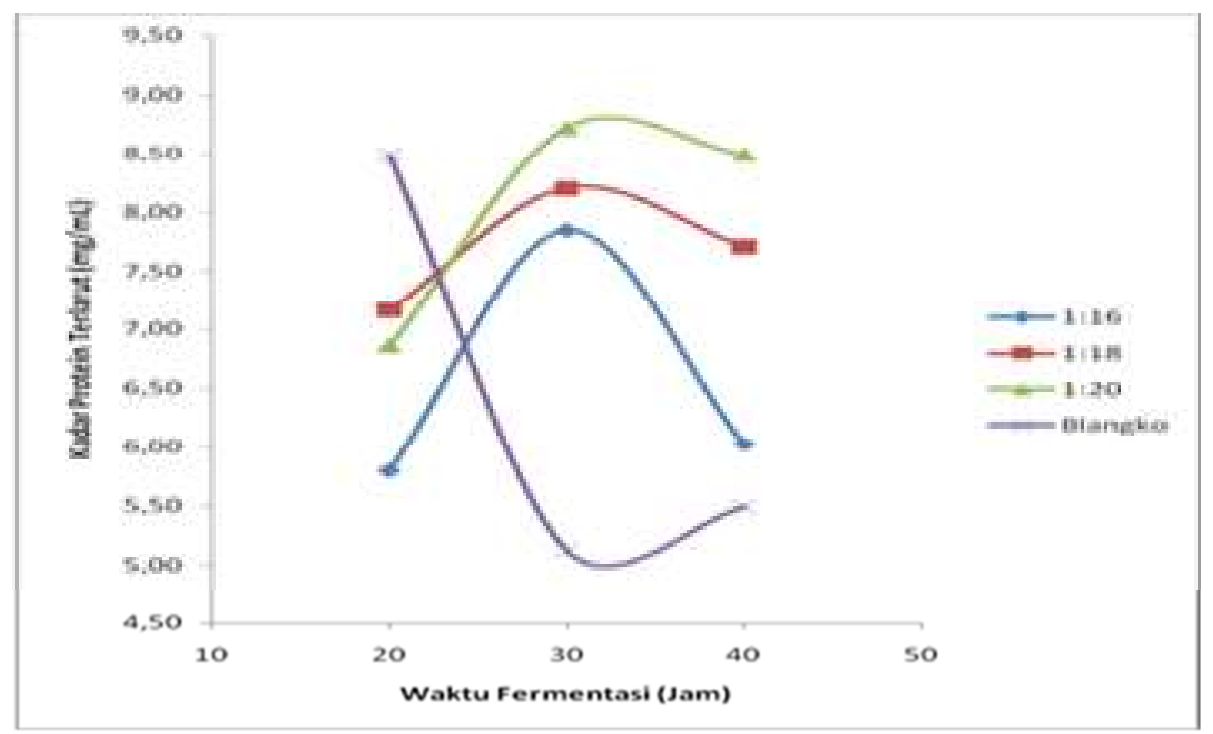

Gambar 6. Hubungan Antara Waktu Fermentasi dengan Kadar Protein Terlarut Minuman Fermentasi Biji Durian

Yoghurt berbahan dasar biji durian dengan perbandingan biji:air $=1: 16$, pola kurvanya mengikuti pola kurva blangko, yakni terjadi peningkatan kadar glukosa dari jam ke-20 sampai jam ke-30 lalu terjadi penurunan dari jam ke-30 sampai jam ke-40. Dalam hal ini yang menjadi perbedaan dengan blangko adalah kadar glukosa pada jam ke 20 lebih kecil dibanding blangko. Hal ini terjadi karena glukosa mulai berkurang akibat digunakan oleh bakteri laktat sebagai nutrisinya.

Waktu fermentasi jam ke-20 sampai jam ke-30 yang merupakan fase log, terjadi peningkatan kadar glukosa dan nilainya pada waktu fermentasi jam ke-30 lebih besar dari blangko. Hal ini menunjukkan bahwa bakteri asam laktat mampu mengurai pati menjadi glukosa. Kemungkinan bakteri starter yang berhasil memecah pati menjadi gula adalah $L$. acidophilus. Hal ini merujuk pada pernyataan Rincker et al. (2000), Champ et al. (1983) dan Lee et al. (2001) yang menyatakan bahwa $L$. acidophilus mempunyai aktivitas amilase. Rincker et al. (2000) mengatakan bahwa $L$. acidophilus (strain L23) mempunyai aktivitas amilase yang relatif tinggi ketika menghidrolisis pati jagung, Champ et al. (1983) menemukan suatu strain bakteri golongan Lactobacilus (LEM 220) menyerupai L. acidophilus, yang mempunyai aktivitas amilase, sedangkan Lee et al. (2001) menyatakan L. acidophilus (strain A-4 dan L23) memiliki aktivitas amilolitik yang tinggi pada kaldu yang mengandung pati sebagai satusatunya sumber karbohidrat.

Pada fase stasioner, yaitu pada interval waktu jam ke-30 sampai jam ke-40, terjadi penurunan kadar glukosa yang disebabkan oleh penggunaan glukosa yang tidak diimbangi oleh ketersediaan polisakarida yang hampir habis (pati dan laktosa) atau karena adanya akumulasi asam laktat yang berlebih sehingga menghambat pertumbuhan bakteri.

Berdasarkan Gambar 4, diketahui nilai kadar glukosa yoghurt biji durian dengan perbandingan biji:air $=1: 18$ dan 1:20 berada dibawah blangko. Hal ini menunjukkan bahwa keberadaan biji durian dalam yoghurt dengan konsentrasi tersebut tidak memberikan kondisi lingkungan (misalnya konsentrasi substrat, $\mathrm{pH}$ atau suhu) yang optimal bagi enzim amilase dan $\beta$-galaktokinase yang dimiliki oleh campuran bakteri asam laktat untuk memecah 
polisakarida yang terkandung didalamnya. Yoghurt biji durian yang paling besar kadar glukosanya adalah yoghurt dengan perbandingan biji durian:air $=1: 16$ dengan lamanya fermentasi 30 jam.

Bakteri asam laktat memecah polisakarida menjadi glukosa dimana glukosa tersebut digunakan sebagai sumber energi. Starter bakteri asam laktat yang digunakan, yaitu $L$. delbrueckii subsp. bulgaricus, L. acidophilus, dan $S$. thermophilus, yang tergolong kedalam bakteri asam laktat homofermentatif (Heller, 2001). Bakteri asam laktat homofermentatif adalah jenis bakteri yang memproduksi $85 \%$ asam laktat dari glukosa (Lactospore, 2000). Bakteri ini menggunakan jalur EmbdenMeyerhof-Parnas (EMP) untuk menghasilkan piruvat dari glukosa dan mereduksinya menjadi asam laktat (Paustian, 2000). Analisis total asam minuman fermentasi biji durian perlu dilakukan untuk menentukan pengaruh waktu fermentasi terhadap total asam pada yoghurt.

Analisis total asam dilakukan dengan metode titrasi. Hubungan antara lamanya fermentasi dengan total asam ditunjukkan dalam Gambar 5. Berdasarkan Gambar 5, pada kurva blangko terlihat total asam meningkat pada interval waktu fermentasi jam ke-20 sampai jam ke-30. Hal ini mengindikasikan bahwa telah terjadi peningkatan aktivitas pengubahan glukosa menjadi asam laktat karena bakteri berada pada fase log-nya. Pada fase ini aktivitas pembelahan atau pelipatgandaan jumlah bakteri berada pada kondisi optimal, sehingga kebutuhan akan glukosa juga meningkat untuk dirombak menghasilkan energi yang dibutuhkan selama proses pembelahan sel-sel bakteri tersebut, akibatnya total asam dari minuman fermentasi menjadi naik.

Pada interval waktu fermentasi jam ke-30 sampai jam ke-40 terjadi penurunan kurva blangko yang menunjukkan bahwa pada interval waktu fermentasi tersebut total asam laktat menurun. Menurunnya total asam blangko dikarenakan pada fase ini kadar glokosa semakin berkurang yang menyebabkan bakteri memanfaatkan asam amino bebas yang terkandung dalam yoghurt sebagai sumber energi dalam jumlah yang banyak. Peningkatan dari pemanfaatan asam amino amino bebas ini menyebabkan terjadinya peningkatan pula pada aktivitas penggunaan asam amino. Asam amino dipecah oleh bakteri dalam dua tahap yaitu deaminasi (pelepasan gugus amina dari asam amino) dan transaminasi (perpindahan gugus amina dari asam amino ke akseptor $\alpha$ ketoglutarat) (Prescott et al., 1996). Proses deaminasi beberapa asam amino oleh $S$. thermophilus menghasilkan amonia $\left(\mathrm{NH}_{3}\right)$ dalam jumlah yang banyak (Groux, 1973 dalam Zourari et al., 1992). Selain itu, S. thermophilus mempunyai enzim urease yang memecah urea susu menjadi $\mathrm{CO}_{2}$ dan $\mathrm{NH}_{3}$ (Miller \& Kandler, 1967; Tinson et al., 1982; Juillard et al., 1988 dalam Zourari et al., 1992). Kedua hal tersebut yang menyebabkan alkalinasi di medium pertumbuhan (minuman fermentasi) (Spinner \& Corrieu, 1989; Famelart \& Maubois, 1988; Zourari et al., 1991 dalam Zourari et al., 1992), sehingga total asam di fase log pada blangko menjadi turun.

Total asam yoghurt biji durian dengan tiga variasi konsentrasi biji durian pada tiga waktu fermentasi berada diatas nilai blangko. Hal ini menunjukkan bahwa bakteri asam laktat memanfaatkan glukosa hasil hidrolisis pati yang terkandung pada biji durian sebagai sumber energi. Pola kurva yoghurt dengan perbandingan biji:air $=1: 16$ dan 1:20 sama seperti blangko, yakni terjadi kenaikan kurva di interval waktu fermentasi jam ke-20 sampai jam ke-30 dan penurunan kurva di interval waktu fermentasi jam ke-30 sampai jam ke-40. Yoghurt dengan perbandingan biji:air $=1: 18$ polanya berbeda dengan blangko, yakni 
diinterval waktu fermentasi jam ke-30 sampai jam ke-40 terjadi kenaikkan kurva yang disebabkan proses alkalinasi pada kosentrasi biji durian tersebut tidak berjalan dengan optimal. Yoghurt yang paling besar total asamnya adalah yoghurt dengan perbandingan biji durian:air = 1:16 dan lama fermentasi 30 jam. Penentuan total asam pada cairan yoghurt dilakukan dengan cara titrasi.

Karakteristik terkuat dari produk minuman fermentasi adalah keasaman. Derajat keasaman minuman fermentasi dapat diwakili oleh nilai $\mathrm{pH}$ dari minuman fermentasi tersebut. Hubungan antara lamanya fermentasi dengan nilai pH minuman fermentasi biji durian ditunjukkan dalam Gambar 6 dibawah ini. Pada blangko terjadi penurunan nilai $\mathrm{pH}$ pada interval waktu fermentasi antara jam ke-20 sampai jam ke-30. Hal ini menandakan keasaman blangko meningkat pada interval waktu tersebut. Peningkatan pada keasaman blanko disebabkan oleh adanya peningkatan akumulasi asam laktat yang dapat meningkatkan konsentrasi $\mathrm{H}^{+}$karena asam laktat merupakan donor $\mathrm{H}^{+}$.

Nilai $\mathrm{pH}$ pada interval waktu fermentasi jam ke-30 sampai jam ke-40 terjadi kenaikan karena keasaman blangko turun. Penurunan keasaman blanko di interval waktu tersebut disebabkan adanya penurunan konsentrasi asam laktat karena proses alkalinasi sehingga konsentrasi ion $\mathrm{H}^{+}$dalam blangko juga turun. Nilai $\mathrm{pH}$ yoghurt biji durian dengan tiga variasi konsentrasi biji durian pada tiga waktu fermentasi tidak mempunyai perbedaan yang signifikan dan berada diantara 3,5-4,0. Nilai pH yoghurt yang berada diantara 3,5-4,0 menandakan semua sampel yoghurt bersifat asam dan tidak jauh dari kisaran $\mathrm{pH}$ susu fermentasi sebesar 3,8-4,6 (Oberman \& Libudzisz, 1998 dalam Dwi, 2005). Bakteri asam laktat membutuhkan asam amino untuk mensintesis protein. Bakteri tersebut mendapat asam amino dari lingkungannya dengan cara memecah protein menggunakan enzim protease eksoseluler (yang dimiliki Lactobacillus), menjadi fraksi-fraksi protein dengan berat molekul rendah. Fraksi-fraksi protein dengan berat molekul rendah ini dipecah menjadi asam amino-asam amino bebas dengan menggunakan enzim diproteinse atau amino-proteinse yang dimiliki $S$. thermophilus (Desmazeaud \& Juge, 1976 dalam Zourari et al., 1992) dan enzim diproteinse atau amino- proteinse yang dimiliki L. bulgaricus (EI Soda \& Desmazeaud, 1982 dalam Zourari et al., 1992). Hubungan antara waktu fermentasi dengan kadar protein terlarut dalam yoghurt biji durian ditunjukkan pada Gambar 5 dibawah ini. Pada blangko terjadi penurunan kadar protein terlarut di interval waktu fermentasi jam ke-20 sampai jam ke-30 karena aktivitas pembelahan atau pelipatgandaan jumlah bakteri berada pada kondisi optimal, sehingga bakteri membutuhkan asam amino dalam jumlah yang besar. Implikasi dari fase log ini adalah protein-protein terlarut banyak yang dipecah menjadi asam amino-asam amino bebas sehingga jumlah protein tersebut menjadi turun.

Protein terlarut berada dalam jumlah yang sedikit sedangkan asam amino bebas berada dalam jumlah yang banyak pada interval waktu fermentasi jam ke-30 sampai jam ke-40, yaitu pada fase stasioner. Keadaan ini menyebabkan bakteri lebih fokus untuk memanfaatkan asam amino bebas yang sudah ada dibanding melakukan hidrolisis terhadap protein, sehingga kandungan protein terlarutnya juga dapat dikatakan tetap atau agak naik.

Jumlah protein terlarut dengan waktu fermentasi jam ke-20 pada yoghurt biji durian dengan tiga variasi konsentrasi berada dibawah blangko. Namun, pada waktu fermentasi jam ke-30 hal yang terjadi justru sebaliknya, yaitu jumlah protein terlarut berada jauh berada 
diatas blangko. Hal ini menandakan bahwa pada fase log, bakteri sudah menggunakan biji durian sebagai salah satu sumber protein. Jumlah protein dalam yoghurt yang besar menyebabkan jumlah protein yang terbentuk lebih besar dibanding protein yang dipecah menjadi asam amino, sehingga dari kurva terlihat nilai kadar protein pada fase log meningkat dan jauh lebih besar dibanding blangko.

Pada fase stasioner, yaitu pada interval waktu fermentasi jam ke-30 sampai jam ke-40 terjadi penurunan kadar protein pada ketiga variasi konsentrasi. Penurunan tersebut dikarenakan pada fase stasioner, jumlah protein yang besar dalam yoghurt biji durian dengan jumlah populasi bakteri yang tetap menyebabkan aktivitas penurunan kadar protein sebanding dengan aktivitas penggunaan asam amino, sehingga kandungan protein terlarutnya sedikit menurun atau dapat dikatakan tetap. Diantara ketiga variasi konsentrasi minuman fermentasi biji durian, minuman fermentasi biji durian yang memiliki kadar protein terlarut tertinggi adalah dengan perbandingan konsentrasi 1:20 dengan lama fermentasi 30 jam.

\section{Kesimpulan}

Berdasarkan penelitian ini dapat disimpulkan bahwa biji durian dapat digunakan sebagai media fermentasi bagi bakteri asam laktat. Lamanya fermentasi dan konsentrasi biji durian berpengaruh terhadap kandungan kimiawi dari minuman fermentasi biji durian. Perbandingan biji durian:air $=1: 20$ pada waktu fermentasi 30 jam menghasilkan yoghurt dengan kandungan protein yang paling tinggi. Perbandingan biji durian:air $=1: 16$ dengan lama fermentasi 30 jam menghasilkan yoghurt yang memiliki kadar glokusa dan total asam yang paling tinggi. Penampilan fisik dari yoghurt adalah berupa larutan kental atau semipadat yang berwarna krem dan berbau tajam khas produk fermentasi bakteri asam laktat.

Untuk memperoleh kandungan kimiawi (gula pereduksi atau protein terlarut) yang tinggi dalam yoghurt biji durian maka perlu dilakukan penelitian lebih lanjut tentang waktu dan suhu pengeringan yang optimal pada saat pembuatan serbuk biji durian, pengaruh penambahan gula dan susu skim, serta pengaruh suhu fermentasi pada pembuatan yoghurt biji durian.

Perlu dilakukan penelitian lebih lanjut yaitu uji organoleptik (uji penerimaan konsumen), karakteristik kimiawi, fisika, dan biologis seperti kadar lemak, kadar abu, cemaran mikroba, dan jenis-jenis asam atau senyawa volatil yang terkandung dalam yoghurt biji durian agar dapat memenuhi standar yoghurt yang sesuai Standar Nasional Indonesia (SNI).

\section{Penghargaan}

Peneliti mengucapkan terima kasih dan penghargaan sedalam-dalamnya kepada: Direktorat Jenderal Perguruan Tinggi (DIKTI) Departemen Pendidikan Nasional dan Lembaga Penelitian (LEMLIT) Universitas Negeri Jakarta yang telah memberikan fasilitas berupa pendanaan. Serta Dekan FMIPA dan seluruh staf pengajar Jurusan Kimia UNJ atas kerjasamanya yang baik.

\section{Daftar Pustaka}

Adolfsson, O., S.N. Meydani, \& R.M. Russell. 2004. Yoghurt and gut Function. American Journal of Clinical Nutrition 80:245-56. 
Aurand, L. W., A. E. Woods, dan M. R. Wells. 1978. Food Composition and Analysis. Van Nostrand Reinhold Company, New York.

Buckle, K. A., R.A. Edward, G.H. Fleet, dan M. Wooton. 1987. Ilmu Pangan. Terj. dari Food Science, oleh Purnomo, Hadi \& Adiono. Penerbit UI Press, Jakarta.

Champ, M., Odette Szylit, P. Raibaud, dan Nadra AÃ-ut-Abdelkader.1983. Abstract: Amylase Production by Three Lactobacillus Strains Isolated from Chicken Crop. www.blackwellsynergy.com, 3 Juni 2011, pkl. 20.44 WIB.

Commtechlab, 2008. Lactobacillus acidophilus. http://commtechlab.msu.edu, 26 Januari 2012, pkl.17.08 WIB.

Courtin, P \& Rul, F. 2003. Interaction Between Microorganisms in a Simple Ecosystem: Yoghurt Bacteria as a Study Model. Lait. 84: 125-134.

Dwi, W. 2005. Karakteristik Kimiawi Minuman Probiotik Kaya Beta-Karoten dari Sari Ubi Jalar Oranye, Prosiding Seminar Nasional dan Gelar Makanan Tradisional 2005:A-62 - A-69.

Endra, L. 2005. Rahasia Dibalik Warna Ubi Jalar. Canopy 47:26-27.

Guchte, M. van de., S. Penaud, C. Grimaldi, V. Barbe, K. Bryson, P. Nicolas, C. Robert, S. Oztas, S. Mangenot, A. Couloux, V. Loux, R. Dervyn, R. Bossy, A. Bolotin, J.M. Batto, T. Walunas, J.F. Gibrat, P. Bessières, J. Weissenbach, S. D. Ehrlich, dan E. Maguin. 2006. The Complete Genome Sequence of Lactobacillus bulgaricus Reveals Extensive and Ongoing Reductive Evolution, www.pnas.org/cgi/doi/10.1073, 11 Agustus 2011, pkl.13.09 WIB.

Heller, K. J. 2001. Probiotic Bacteria in Fermented Foods: Product Characteristics and Starter Organisms. Am J Clin Nutr 2001;73(suppl):374S-9S.

Lactospore. 2000. Background Information on Lactic Acid Bacteria. www.lactospore.com, 9 Pebruari 2012, pkl.17.35 WIB.

Lee, H.S., SE Gilliland. \& S Carter. 2001. Abstract: Amylolytic Cultures of Lactobacillus acidophilus: Potential Probiotics to Improve Dietary Starch Utilization. www.blackwell-synergy.com, 3 Juni 2011, pkl. 20.57 WIB.

Lowry, O.H., N.J. Rosebrough, A.L. Farr, dan R.J. Randall. 1951. Lowry's Assay for Total Protein. J.Biol.Chem. 193: 265-275.

Mecasys. 2008. The Lowry Assay. www.mecasys.co.kr, 28 September 2011, Pk. 14.04 WIB.

Nelson, N. 1944. A Photometric Adaptation of Somogyi Method for the Determination of Glucose. www.jbc.org, 2 September 2011, pkl.12.45 WIB.

Pierce. 2007. Chemistry of the Modified Lowry Protein Assay. www.piercenet.com, 20 Januari 2011, pkl.14.51 WIB.

Prescott, L. M., John P. H, \& Donald A. K. 1996. Microbiology; Thirth Edition. Wm. C. Brown Publishers, Chicago: $903 \mathrm{hlm}$. 
Prihatman, K. 2000. Durian (Bombaceace sp.). www.ristek.go.id, 28 Mei 2011, pkl.15.22 WIB.

Rincker, M.J., S.D. Carter and S.E. Gilliland. 2000. Potential of Amylolytic Cultures of Lactobacillus acidophilus to Improve Dietary Starch Utilization in Weanling Pigs. www.okstate.edu/research/2000rr, 5 Juni 2011, pkl. 14:31 WIB.

Somogyi, M. 1952. Notes on Sugar Determination. www.jbc.org, 4 Februari 2012, pkl.17.55 WIB.

Surajudin, Fauzi R. K, \& Dwi P. 2005. Yoghurt; Susu Fermentasi yang Menyehatkan. Agromedia Pustaka, Jakarta: $70 \mathrm{hlm}$.

Unibas. 2008. Streptococcus thermophilus. www.unibas.it, 26 Januari 2012, pkl.17.16 WIB.

Widowati, S dan Misgiyarta. 2003. Efektifitas Bakteri Asam Laktat (BAL) dalam Pembuatan Produk Fermentasi Berbasis Protein/Susu Nabati. www.indobiogen.or.id/terbitan/prosiding, 24 Juni 2011, pkl.10.44 WIB.

Zourari, A., J.P. Accolas, dan M.J. Desmazeaud. 1992. Metabolism and Biochemical Characteristics of Yoghurt Bacteria. A Review. Lait 72: 1-34. 